Volume 2

Number 2 Teaching Secrecy

January 2021

\title{
State Secrecy: A Literature Review
}

Stephane Lefebvre

Independent Researcher, stephane.lefebvre@rogers.com

Follow this and additional works at: https://scholarworks.sjsu.edu/secrecyandsociety

Part of the National Security Law Commons, Political Theory Commons, and the Theory, Knowledge and Science Commons

\section{Recommended Citation}

Lefebvre, Stephane. 2021. "State Secrecy: A Literature Review." Secrecy and Society 2(2). https://doi.org/10.31979/2377-6188.2021.020209 https://scholarworks.sjsu.edu/ secrecyandsociety/vol2/iss2/9

This Documents is brought to you for free and open access by the School of Information at SJSU ScholarWorks. It has been accepted for inclusion in Secrecy and Society by an authorized administrator of SJSU ScholarWorks. For more information, please contact scholarworks@sjsu.edu.

\section{(c) (1)}

This work is licensed under a Creative Commons Attribution 4.0 License. 


\title{
State Secrecy: A Literature Review
}

\begin{abstract}
What is secrecy? What is a state secret? Which state secrets deserve protection from disclosures? How are state secrets protected from disclosure? In this review, I use these questions as an organizing framework to review the richness of a very disparate, largely US-centric, but also multidisciplinary literature. In doing so, I highlight the social nature of secrecy - that it is a social construct with social effects and consequences - and the need for further research to unveil those rationalities that specific discourses on state secrecy put forward to legitimize the nondisclosure of state secrets.
\end{abstract}

Keywords

disclosure, government secrecy, literature review, secrecy, state secrets

This documents is available in Secrecy and Society: https://scholarworks.sjsu.edu/secrecyandsociety/ 


\title{
State Secrecy: A Literature Review
}

Stéphane Lefebvre ${ }^{1}$

\begin{abstract}
What is secrecy? What is a state secret? Which state secrets deserve protection from disclosures? How are state secrets protected from disclosure? In this review, I use these questions as an organizing framework to review the richness of a very disparate, largely US-centric, but also multidisciplinary literature. In doing so, I highlight the social nature of secrecy - that it is a social construct with social effects and consequences and the need for further research to unveil those rationalities that specific discourses on state secrecy put forward to legitimize the nondisclosure of state secrets.
\end{abstract}

\section{Keywords}

disclosure, government secrecy, literature review, secrecy, state secrets

The world has no shortage of openly available data to expand its knowledge. While it was once very difficult to know what was happening in remote and shielded areas of the world, social media, commercial data mining and commercial satellite imagery, among others, have opened up

1 Independent Researcher, Ottawa, Canada. Stéphane Lefebvre previously spent over 20 years working in various intelligence and research-related positions in Canada's federal government. He has published extensively in the fields of intelligence studies and Slavic military studies. His latest work on state secrecy was published in 2018 and 2019: "Why Are State Secrets Protected from Disclosure? The Discourse of Secret Keepers," The International Journal of Intelligence, Security, and Public Affairs 20 (2018): 204-229 and "What Do Judges Say on the Protection of Intelligence Secrets?" Intelligence and National Security 34 (2019): 62-77. The views expressed herein are his own and do not reflect the official position of any of the government of Canada departments or agencies he has worked for. 
new vistas of knowledge. ${ }^{1}$ Compounded by massive leaks of state secrets by Manning and Snowden in the 2010s, this new access to data and knowledge has raised a fundamental question about the ability of state officials and political leaders to keep their activities away from prying eyes: Is nothing secret $?^{2}$ Of course, the question is facetious. States worldwide still have plenty of secrets to protect from unauthorized disclosure.

In fact, leakers and spies are vigorously pursued everywhere, and the United States is no exception. State officials who disclose without authorization secrets they are entrusted with, especially to an agent of another state, commit a serious crime against their own state. In modern democracies, such acts are at least considered political offences or at worst treason, and can be severely punished. In comparison with most other crimes, however, the unauthorized disclosure of state secrets and its prosecution in advanced democracies are relatively rare events.

Since $9 / 11$, US scholars have paid particular attention to state secrets and raised concerns about many issues. Most importantly, they have questioned the superabundance of state secrets, the ability of oversight and review bodies to regulate any abuse of secrecy, and the effects and transparency costs of secrecy.

For example, in Democracy in the Dark/The Seduction of Government Secrecy, legal counsel Frederick A. O. Schwarz, Jr. argues that the United States has entered a "Secrecy Era" characterized by a superabundance of 
state secrets designed not to protect America but to keep what is reprehensible from Americans, and an entrenched and seductive security culture within the walls of the American government. His antidote to secrecy, necessary to buttress democracy, is openness. ${ }^{3}$ Schwarz's views accord well with those who believe that governments should be more transparent and that there should be fewer state secrets than there are. In Secrecy in the Sunshine Era, political scientist Jason Ross Arnold in turn observes that executive secrecy is as pervasive in Democratic as Republican administrations, predates $9 / 11$, and resists the sunshine era that freedom of information laws were supposed to usher. ${ }^{4}$

In Secrets and Leaks: The Dilemma of State Secrecy, professor of politics Rahul Sagar argues that the contemporary debate surrounding state secrecy in the United States is not about its legitimacy but instead about whether or not there is a proper regulatory framework in place to ensure that it will not be abused. Devising such a framework, he contends, is very difficult to do. ${ }^{5}$ Hence, to avoid regulatory capture inherent in any single authority, he further argues that the possibility of unauthorized disclosures of state secrets "provides the most effective and credible guarantee that those who have the formal authority over state secrecy cannot systematically use it to their own advantage, ${ }^{\prime 6}$ even though leaks of state secrets can be done both for good and for ill. ${ }^{7}$ In When Should State Secrets Stay Secret? political scientist Genevieve Lester argues that US intelligence 
accountability and oversight mechanisms (which largely operate in secret so as not to endanger national security) contribute to greater secrecy instead of expanding public access to intelligence information. ${ }^{8}$ Her analysis of these mechanisms shows that they have for effect to reinforce state secrecy.

Finally, in Democracy Declassified: The Secrecy Dilemma in National Security, political scientist Michael Colaresi examines the negative effects and transparency costs of secrecy in foreign policy, and argues, using counterfactual examples, that an excess of authorized disclosures of foreign policy secrets "is likely to undercut the public benefit of the [foreign] policy" under discussion. ${ }^{9}$ Importantly, he acknowledges that keeping secrets may sometimes delegitimize a particular foreign policy, but be that as it may, what remains important is for the state to have significant justifications. ${ }^{10}$ To bridge the gap in accountability created by the existence of state secrets, he argues that combined solutions such as transparency cost deflation (secrets lose their value over time thus allowing ex-post accountability) and the empowerment of oversight and accountability mechanisms external to the executive branch of government can increase the probability of public consent to the state's foreign policy choices.

What these authors tell us is that state secrets are ubiquitous, well entrenched, and sometimes necessary for the conduct of state activities and therefore here to stay. The best that can be hoped is for states to devise and implement adequate and efficient oversight and review bodies to avoid 
abuses and minimize the costs of secrecy to the state and society. Yet, do we really have a good grasp of what secrecy is, what a state secret is, of which state secrets are deserving of protection from disclosures, and of how state secrets are protected from disclosure? In this article, I use these questions as an organizing framework to overview the richness of a very disparate, largely US-centric, but also multidisciplinary literature. This literature overview thus looks at how a variety of scholars have answered these questions. In doing so, it highlights the social nature of secrecy (that it is a social construct with social effects and consequences) and the need for further research to unveil those rationalities that specific discourses on state secrecy put forward to legitimize the nondisclosure of state secrets. Its particular contribution to the literature on state secrecy is in showing that our understanding of the subject can be enriched through a wider, multidisciplinary approach.

\section{Overview}

Social scientists have consistently neglected the study of secrecy in complex and large organizations and instead paid a significant amount of attention to the study of non-state secrecy in small organizations, such as secret societies and religious sects. ${ }^{11}$ The renewed interest in secrecy and esotericism shown by academics, novelists and popular entertainers in the 1990s only compounded that situation, since it did not lead to a better understanding of the overall subject. In Urban's assessment, "the study of 
secrecy has remained disappointingly general, universalistic, and largely divorced from social and historical context." ${ }^{12}$ Social scientists, especially, have spent little time theorizing about the "origins, nature, workings, and consequences of secrecy within social systems."13

Balmer's assertion that "[s]ecrecy has never been a major topic of research in social science, although it has not been entirely neglected," is indeed correct. ${ }^{14}$ That said, it should be noted that a distinct field of studies centered on secrecy is being developed and supported by a university-based, peer-reviewed, and interdisciplinary journal entitled Secrecy and Society. ${ }^{15}$ With its first issue published in 2016, the journal aims at exploring secrecy in its various manifestations and through a variety of theoretical and cultural underpinnings. ${ }^{16}$ In doing so, it is building a scholarly community on the subject of secrecy, making a legitimate and major topic of research.

Where the study of secrecy has particularly not been neglected, of course, is in its breach. As Erickson and Flynn noted, "[s]ecrecy is [...] likely to be examined in terms of a deviant form of organizational behaviour; it is the illegal and inappropriate use of secrecy that is emphasized." ${ }^{17}$ Sociologists of work have indeed studied that problem, ${ }^{18}$ and argued that keepers of state secrets may have predispositions - because of their personality, experiences (for example of perceived injustice), or motives not to obey the law, but the manner in which they interact with organizational factors (such as culture, norms, procedures, reward system, and attitude 
toward employees) may either "increase or decrease the probability of deviant behaviours. ${ }^{19}$ Espionage, however, is the deviant form of behavior that has most interested scholars and excited popular writers. ${ }^{20}$ But the means by which foreign nations or other adversaries attempt to obtain state secrets, and how to defeat them, are well covered by counterintelligence experts in the field of intelligence studies. ${ }^{21}$

Despite the general neglect of social scientists, there is a large but disparate literature on state secrets. The graphic below (called an NGram) shows the relative usage frequency from 1800 to 2008 (the latest date that can be used) of the terms "state secrets" in the millions of printed sources digitally available to Google (a corpus of books published in English in the United States). ${ }^{22}$

Figure 1: NGram for "state secrets"

\section{Google Books Ngram Viewer}

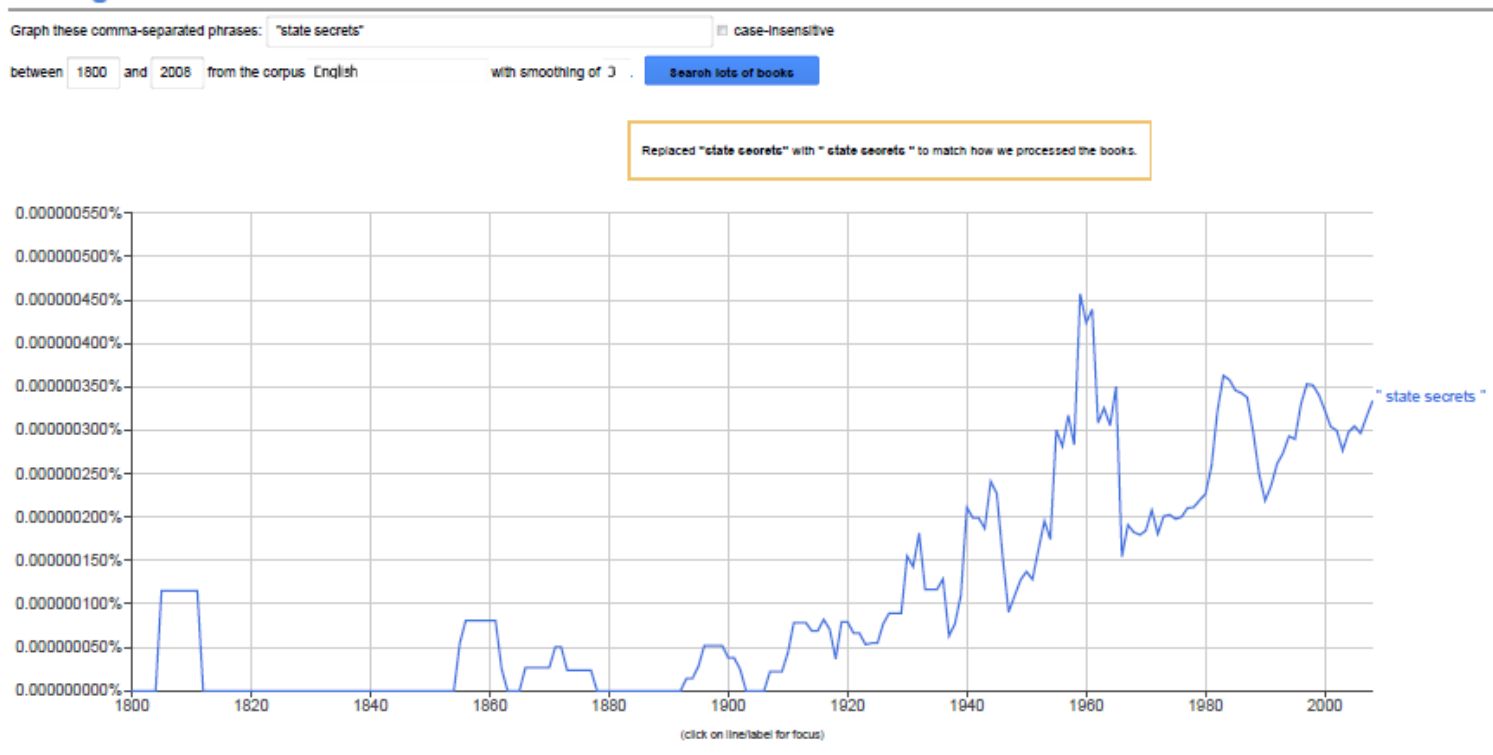


Source: Shen et al (2016). ${ }^{23}$

The NGram clearly shows that the ascendency of the use of the terms

"state secrets" correlates very closely with the advent of the Cold War.

Thompson offers an assessment of this US-centric literature:

Government secrecy certainly has not been ignored. Many scholars and reformers have examined it critically, and government bodies have investigated the problem. [...] Nevertheless, most of the literature on government secrecy neglects the fundamental democratic values underlying the problem and focuses instead on the laws and policies that regulate secrecy, patterns of abuses by individual officials, or particular practices such as executive privilege and national security. ${ }^{24}$

\section{What is Secrecy?}

Secrecy, of course, "has a life outside of the demands and desires of the state ${ }^{\prime 25}$ and that life has been examined as both a normal and deviant form of personal behavior. This is the world of the intimacy of everyday life, where emotional, sexual and psychological closeness "has traditionally desired secrecy: the trustworthiness of friends, the discretion of lovers, the enshrined secrecy of the confessional, of the doctor's surgery and the psychiatrist's couch." ${ }^{26}$ Human beings keep secrets between themselves and from others as a matter of fact. It is part of their daily routines and, as Joel Feinberg notes, "life would be hardly tolerable if there were no secrets we could keep (away from the 'street'), no preserve of dignity, no guaranteed solitude." ${ }^{27}$ Prominent sociologists like Georg Simmel ${ }^{28}$ and Irving Goffman ${ }^{29}$ 
and more recently legal scholar William Ian Miller ${ }^{30}$ indeed all have argued that most of us intentionally hide or fake things about ourselves in our everyday lives. ${ }^{31}$ For Simmel, this secrecy that we exercise is "one of the greatest accomplishments of humanity." ${ }^{\prime 2}$ This is the case, he believes, because without secrecy life would just not be the same as "many sorts of purposes could never arrive at realization." ${ }^{33}$ Such a sociological interest in secrecy has obviously "existed for some time, although it could not be said that the field is at all coherent, or that it constitutes a disciplinary subfield." ${ }^{34}$ Although this observation is apt, I will highlight a few contributions that I think are interesting and valuable.

In their discussion of capitalism and schizophrenia, philosophers Gilles Deleuze and Félix Guattari problematize the notion of the secret by asserting that it must have a content in a form that is covered, isolated or disguised, given its role to suppress formal relations. ${ }^{35}$ For them as well, the secret is in essence a sociological notion; it is invented and a collective assemblage, and therefore not a static notion. In fact, how it is perceived can change and differ from person to person; it secretly influences, spreads and propagates. ${ }^{36}$ In short, they write,

the secret, defined as a content that has hidden its form in favor of a simple container, is inseparable from two movements that can accidentally interrupt its course or betray it, but are nonetheless an essential part of it: something must ooze from the box, something will be perceived though the box or in the half-opened box. ${ }^{37}$ 
Organizational theorists Jana Costas and Christopher Grey opine in a similar direction, but in a slightly more nuanced manner:

Secrecy refers to the [social] process of keeping secrets, while secret refers to the content, the actual 'things'- more precisely, the information about 'things'- that are being intentionally concealed. [...] the keeping of a secret requires continuing concealment or, alternatively, the breaking of the secret through revelation. This means that for secrets to exist actors need to constantly engage in practices of concealment [...]. Intentional concealment is a social phenomenon in that it is carried out by social actors in concert and is likely to involve a rich array of symbolic and ritualistic practices whereby, for example, the signing of a confidentiality agreement or the giving of a promise (e.g. formally, on oath or, informally, "on my life") are potent markers of the boundary between being or not being 'in the know'. Indeed, secrecy has potential social consequences (upon those social actors and others) above and beyond the concealment of information, one example being the possible awe and mystery that surrounds them (mysterium) but others include, potentially, shame or guilt or other effects on identity $[\ldots] \cdot{ }^{38}$

Secrecy, therefore, has more than one function. While in the eyes of the state it is about the protection of information or material from unauthorized disclosure for their intrinsic value, for secret keepers it can also be about their protection from disclosure for symbolic value. ${ }^{39}$ Pierre Bourdieu, a sociologist, notes too that secrecy has a symbolic function: it is "a rare, scarce resource or valuable commodity, which confers a special kind of prestige and so determines one's status within a given hierarchy of power. ${ }^{\prime \prime 0}$ So did history professor Janet Brodie, who explains well the symbolic impact on individuals entrusted with state secrets:

To obtain [a security] clearance carried powerful symbolic meaning, providing access to arcane knowledge and changing 
the way one regarded others and was, in turn, regarded. Once one obtained access to classified information, those without such access appeared uninformed, even ignorant. It changed the way one regarded peers, colleagues, and the scope of intellectual exchange. ${ }^{41}$

That secrecy may not encapsulate any valuable state secret, however, has long been recognized by keepers of state secrets themselves. Worldrenown novelist John Le Carré, who served in British intelligence at the height of the Cold War, explains the symbolic power that the lure of secrecy had for him:

[it provided] a means of outgunning people we would otherwise be scared of; of feeling superior to life rather than engaging in it; as a place of escape, attracting not the strong in search of danger, but us timid fellows, who couldn't cope with reality one calendar day without the structures of conspiracy to get us by. ${ }^{42}$

Oxford historians during their Second World War military service made a similar point. Hugh Trevor-Roper, then serving with fellow historians in the Radio Security Service, reported in his personal journal words by his colleague Stuart Hampshire:

Stuart Hampshire observed that S.I.S. [British Secret Intelligence Service, popularly known as MI6] values information in proportion to its secrecy, not to its accuracy. They would attach more value, he said, to a scrap of third-rate and tendentious misinformation smuggled out of Sofia in the flybuttons of a vagabond Rumanian pimp than to any intelligence deduced from a prudent reading of the foreign press. And of course he's quite right. ${ }^{43}$

Marxist theorist Guy Debord added to this discussion on the function of secrecy by arguing that generalized secrecy is a principal feature of the modern capitalist system, that it stands "behind the spectacle, as the 
decisive complement of all its displays and, in the last analysis, as its most vital operation. ${ }^{\prime 44}$ In other words, he noted later, "[o]ur society is built on secrecy," with both private sector secrets and state secrets and an increasing number of people "trained to act in secret." ${ }^{45}$ In such a society, "[t]he spectator is simply supposed to know nothing, and deserve nothing." 46 Taking the left-wing terrorist threat of the 1980 s to illustrate his argument, he wrote that "[t]he spectators must certainly never know everything about terrorism, but they must always know enough to convince them that, compared with terrorism, everything else must be acceptable, or in any case more rational and democratic. ${ }^{\prime 47}$ Spectators in fact do accept the existence of secrecy, that "there are inevitably little areas of secrecy reserved for specialists." ${ }^{48}$ But it would be very difficult for them, in any event, to determine whether state secrets are legitimate or not:

Unnecessary governmental secrecy remains a pernicious problem, but it is impossible to prove that point empirically because of the very nature of secrecy: we do not know what the government knows and cannot assess whether some of the information currently out of public view should be disclosed for the benefit of democratic self-governance. ${ }^{49}$

Given the foregoing discussion, Simmel was probably correct to say that:

Secrecy is a universal sociological form, which, as such, has, nothing to do with the moral valuations of its contents. On the one hand, secrecy may embrace the highest values [...] On the other hand, secrecy is not in immediate interdependence with evil, but evil with secrecy. [...] Secrecy is, among other things, also the sociological expression of moral badness. ${ }^{50}$ 
This observation provides a close linkage to Jody Dean's argument that secrecy is inherently something that is political, invoked to "achieve particular political ends. ${ }^{51}$ As an example, she asserts that the way secrecy was invoked after 9/11 was in terms of a crucial element necessary to save lives and prevent future occurrences of terrorist acts. It means, in other words, that "[t]he knowledge contained in the secret is a guarantor of security. ${ }^{\prime 22}$ Hence, security would be a byproduct of secrecy. ${ }^{53}$ Dean also observes that the same secrecy prevents public debate while serving as a source of legitimization to state action. This serves, of course, the ends of politics, despite the fact that "[p]ublicity is [...] a condition for legitimacy insofar as the secret holds that information decisive for debate." ${ }^{54}$ Joseph Masco, finally, goes further than Dean by assuming that the ends of politics also include using secrecy "to create new realities." ${ }^{55}$ According to him:

In this post-World War II system, secrecy becomes not just a technology of state power, a means of orchestrating policy and protecting state interests through the withholding of information, but also the basis for an entirely new kind of power: the ability to create new realities. Specifically, in the nuclear age the idea of secret knowledge becomes deployable on its own. Evoking the secret thus becomes a means of claiming greater knowledge, expertise, and understanding than in fact is possible. ${ }^{56}$

The notion of secrecy, overall, is not uniquely tied to the state; it is indeed an integral part of human behavior which makes it a sociological notion and phenomenon that is never fixed in time and place. It also has social consequences that may be highly personal, social or political, and it performs a number of functions beyond the protection of information or 
material, the symbolic and political ones probably being the most tangible. This discussion suggests the content of a secret does not matter as much as the ends to which it is used.

\section{What is a State Secret?}

State secrets are information or material that the state is taking measures to safeguard, deliberately concealing from public view, and refusing to disclose because it would "be contrary to the best interests of the state" to do so. ${ }^{57}$ A state secret is categorized (or classified) as CONFIDENTIAL, SECRET or TOP SECRET on the basis of the degree of injury it would cause to a state's national interest (usually in the areas of national security, national defense and international relations) if it were disclosed to anyone not authorized to be in its possession. ${ }^{58}$ The most guarded state secrets are usually those that "might reveal what government knows about terrorists [and spies], or might compromise intelligence sources and methods, thereby reducing the flow of intelligence [from domestic and foreign sources]"159 if inappropriately disclosed. Thus, the secrets of subnational governments (i.e., provinces, territories, municipalities), private sector information of a confidential nature, and information sensitive for reasons other than the national interest (also known as designated information) are not state secrets. Cabinet confidences can be classified or designated sensitive; if classified they constitute state secrets. ${ }^{60}$ In the United States, the deliberative process (as it relates to government decision- 
making) or executive privilege (as it relates to the presidency and its office) works along similar principles as the Cabinet privilege. ${ }^{61}$

The notion of a state secret is intuitively easy to grasp. Like any other secrets, it has a social existence. However, it also has a formal, legal existence as it is subject to laws and rules adopted by competent authorities (government, parliament) that define "what is to be kept secret and how, who can be entrusted with secrets and what sanctions apply to secrecy breach. ${ }^{\prime 62}$ As Kim Lane Scheppele articulated with respect to social secrets, a state secret can be shallow (a secret that is known publicly to exist, but not its contents) or deep (a secret that it not publicly known to exist) as well. ${ }^{63}$ In their comprehensive definition of secrecy, secret and secrets, Jan Goldman and Susan Maret also distinguish between various types of secrets, including core ("in which the compromise of would result in unrecoverable failure"), essential (denied to adversaries because of their criticality), and subjective (compact, transparent, arbitrary, changeable, and perishable") versus objective (the reverse of subjective). ${ }^{64}$ These typologies are useful in discerning the contents and usefulness of secrets, including those of the state. ${ }^{65}$

A small number of philosophers, it shall be noted, have indirectly tried to answer this section's question for a very long time. In his discussion on publicity in the context of British parliamentary proceedings, Jeremy Bentham, who saw secrecy as an instrument of conspiracy and as a 
characteristic of despotic states, made the important point that publicity - a characteristic of good government under representative democracy - cannot be an absolute principle and that there were circumstances where it ought to be suspended in order to prevent an enemy to gain an advantage, "to injure innocent persons" and "to inflict too severe a punishment upon the guilty." Thomas Hobbes and Benedict de Spinoza had preceded Bentham in arguing that state secrecy should only be evoked in exceptional circumstances, and that it is preferable, in Spinoza's words, "for the honest policies of a state to be obvious to its enemies than for the guilty secrets of tyrants to be kept hidden from its citizens." ${ }^{67}$ Governing in secrecy, Spinoza added, would be "supreme folly": the populace would "judge ill of the same" and give "everything an unfavourable interpretation." ${ }^{68}$ Hobbes, familiar with the notion of arcana imperii (variably translated as invisible power, secret government or secrets of statecraft), thought that publicity was essential on the part of the sovereign to avoid the people being ignorant or misinformed, but that truth should not be exaggerated so as to preserve peace and stability. ${ }^{69}$ Philosopher John Stuart Mill shared the views of Spinoza and Bentham, adding that the public and open discussion of ideas was essential for arriving at the truth. ${ }^{70}$

Complexifying the issue considerably, critical theorist Mark Neocleous more recently argued that the creation and keeping of state secrets has much to do with the material nature of state power than with anything 
else. ${ }^{71}$ It is about the idea of the state as a possessor of knowledge - a gatherer "of all necessary information, both overt and secret, that government needs to fashion its policies and do its work"72 and which it seeks to protect from unauthorized disclosure - that has its own interests to pursue (reason of state), making secrecy a necessary feature or ritual of state power over the last 500 years. ${ }^{73}$ Eliminating state secrecy therefore makes no sense unless the state itself no longer makes any sense. ${ }^{74}$ This speaks again to the function of secrecy, raised in the preceding section. This observation also is reflective of the linkages between state secrecy and bureaucracies made by a number of preeminent theorists.

Sociologist Max Weber famously linked the existence of modern state secrets to the bureaucracy of the state:

secrecy is used to sustain the power interests of the bureaucracy. Indeed, the term "official secret" is an invention of the bureaucracy. And nothing is more fanatically protected by bureaucracy than the concept that secrecy is necessary, an attitude which is not objectively warranted outside those specific areas discussed above [e.g., diplomacy, military administration . $^{75}$

Particularly interested in German politics, Weber argued that the ability of the German parliament at the turn of the $19^{\text {th }}$ Century to control the administration of the state was impeded by parliament's ignorance of state activities, which he attributed "to the fact that officialdom's most important instrument of power is the transformation of official information into secret information by means of the infamous concept of 'official secrecy', which 
ultimately is merely a device to protect the administration from control. ${ }^{176}$

The official [state] secret, from that standpoint, is thus nothing less than a specific invention of the bureaucracy that serves its pure interest. ${ }^{77}$ This notion of bureaucratic self-interest suggests that keepers of state secrets would recognize that interest and hence not disclose secrets without authorization because doing so would be against their self-interest. Weber however conceded that in some cases secrecy can be justified:

As long as competing industries exist, especially competition between different countries, it will be essential to protect at least their technical operations secrets adequately against tendentious publication, and, even more importantly, secrets of a militarytechnical nature. Finally this must also apply to foreign policy deliberations which are still in the balance. ${ }^{78}$ [so as not to endanger or prevent peace]. ${ }^{79}$

Weber's thinking was present in the impactful report of the Commission on Protecting and Reducing Government Secrecy. Established by the US Congress in 1994 and chaired by Daniel Patrick Moynihan, the Commission described the US secrecy system as a regulatory scheme with costs and benefits in need of greater accountability and input from Congress. ${ }^{80}$

Marxists for their part have doggedly pointed out that state or administrative secrecy is a necessary concealment mechanism that the capitalist state uses to give legitimacy to an exploitative accumulation process. ${ }^{81}$ Karl Marx made the simple but still powerful point that the control 
of knowledge, and therefore secrecy, was a fundamental characteristic of the bureaucracy. ${ }^{82}$

Notwithstanding its ideological flavour, Marx's original point has a lot of currency today. In fact, even non-Marxists can appreciate that secrecy is a bureaucratic characteristic that has become "the reigning force in governments around the world - both elected and non-elected. ${ }^{\prime 83}$ The reasons for that, of course, extend beyond supporting the capitalist mode of production. As Peters succinctly notes:

[s]ecrecy has been adopted quite simply to ensure that administrators as public servants will be isolated from shortterm political pressures and be free to make decisions in what they consider to be the 'public interest. ${ }^{84}$

Secrecy, the argument further goes, allows bureaucracies to be neutral, and more effective and autonomous than if they were operating with a high degree of transparency. ${ }^{85}$ In a context where their advice is privileged, bureaucrats are more likely to express themselves freely and frankly with both their subordinates, colleagues and superiors: "unless such an exchange of ideas, trying out of proposals, and general brainstorming is kept confidential, the whole process of reaching a reasoned decision is acutely impeded." ${ }^{\prime 86}$ Moreover, as Michael Reed points out, official secrecy has allowed bureaucrats to monopolize knowledge and expertise in the protection of their own interests and to become "an independent social and political force within modern capitalist political economies and societies." ${ }^{87}$ 
With the advent of the Cold War, the production and protection of state secrets by democratic polities have become increasingly normalized, with the consequence that national security decisions and activities are increasingly invisible to the public. In an important article in 2008, criminologist Willem de Lint analyzes the normalization of security and intelligence - and by direct implications secrecy - in democratic polities. He argues that the intelligence function of the state is increasingly being used within security politics, with the consequence that exclusions and exceptions are becoming a normal course of business, and the basis for decisions that must remain discreet (the use of secret intelligence information in immigration cases in Canada and the United States is a case in point). This is especially becoming apparent in the realm of administrative law $^{88}$ and, in Canada, criminal law. ${ }^{89}$

The problem with a security apparatus that has become "intelligencified," de Lint writes, is that it "produces an intelligence antipolitics in which a cloaked knowledge justifies, penetrates, and at strategic moments overturns popular and state sovereignty.. ${ }^{\prime 90}$ He recognizes the system of exclusion famously expressed by Foucault ${ }^{91}$ that the "intelligencified" practice of knowledge generates, and notes quite rightly that as a system of knowledge intelligence is subject to entry controls, and the use of its data subject to hierarchical filtering (security clearances, trust networks, loyalty measures, etc.) to ensure that there is no unauthorized disclosure. ${ }^{92}$ The key point here is that the exclusion of blanket categories of 
individuals (e.g., homosexuals, communists, gamblers, etc.) from government service in the past was seen as a necessary measure to take to protect state secrecy and a state's national security. ${ }^{93}$

To his process of "intelligentified" governance, de Lint associates rationalities/discourses that conceptualize state secrecy in a particular way both for popular consumption and for those who must protect secrets. A number of them come immediately to mind: the accelerating shift from a post-crime to a pre-crime society in the pursuit of security (with its heavy emphasis on intelligence gathering and the exchange of intelligence across national boundaries, both done with the utmost degree of secrecy ${ }^{94}$ as de Lint argues), the advent of the risk society, ${ }^{95}$ and a renewed emphasis on the use of state coercion by liberal polities (which de Lint refers to as "sovereign and coercive rationalities and techniques [...] within the very territory of the liberal art of government, ${ }^{\prime \prime 6}$ for example, the Canadian Conservative government's "tough on crime" agenda from 2010 to 2015). Keepers of state secrets exposed to these rationalities and with responsibilities to act according to them can be convinced that the protection of state secrets is essential, that not protecting state secrets would increase risks, and that it would reduce the ability of the state to prevent crimes and use coercion efficiently.

The knowledge that makes secrecy so pervasive in national security matters is expressed by national security experts and government lawyers, 
to whom judges usually show a high degree of deference, ${ }^{97}$ and whose security discourse, to borrow from de Lint and Sirpa Virta, "is conceptualized in ways which privilege finitude, certainty, realism and executive authority so that potentially endless ambiguities may be cut short. Security talk offers a variety of closures when exercised to privilege the dominant discourse.."98 As Bourdieu aptly observed, it is only the state and its representatives that are in a position to create an official viewpoint that must be recognized by the court. ${ }^{99}$

While the existence of state secrets is undisputed because they are subject to laws and rules adopted by competent authorities, their meaning is. State secrets can be known and identified once they have been officially disclosed or leaked. Many scholars, however, argue their very existence depends on function, not content; they would not exist without serving a particular purpose. That purpose is a matter of debate and, as de Lint argues, shifting. In that sense, what a state secret is cannot easily be disassociated from one's understanding of the notion of secrecy.

\section{Which State Secrets Deserve Protection from Disclosures?}

The foregoing discussion has partly answered that question. Here, I only intend to supplement this discussion with additional scholarly observations. I do so to highlight the fact that secret keepers are not the only ones to offer reasons to protect state secrets from disclosure. 
In studying the underlying structure of social institutions, Scheppele recognizes that the state can make special claims (e.g., defence and national security claims), and that it "presents a special case" that "deserves special and separate treatment."100 This view is supported by the work of Amy Gutmann and Dennis Thompson, who also make the point that there could be exceptional reasons for the presumption of publicity for politically relevant information to be rebutted by the claims of secrecy.

They contend that there are three principal reason: necessity, liberty and opportunity and deliberation. ${ }^{101}$ The first reason is that secrecy is necessary if making its contents public would defeat its purpose. ${ }^{102}$ In such few cases, secret keepers would be expected to "give an account of the reasons for the secrets, and respond to demands to limit their scope." ${ }^{103}$ The second reason is that unrestrained publicity may negatively affect basic liberty and opportunity, for example when the release of specific and identifiable information violate the personal integrity of officials and citizens. ${ }^{104}$ The third reason is that secrecy sometimes better supports democratic deliberation than not, as long as prospective and retrospective accountability is present. ${ }^{105}$ In that context, deceptive secrets (concealing information to deceive other people), except perhaps in wartime or against criminals, would hardly ever be justifiable because they could not logically be open to prospective accountability. Often, they are those secrets that hide wrongdoing or questionable policies the state believes are right. ${ }^{106}$ Deep 
secrets, which can also be deceptive in nature, are similarly problematic, as only shallow secrets can be challenged. ${ }^{107}$

David Pozen, for his part, has outlined the various consequentialist arguments in support of "state" secrecy in a small number of categories. First, secrecy is necessary to prevent adversaries (like spies, terrorists or criminals) from using disclosed secrets in a manner that would harm national interests or negate the effectiveness of the state in the implementation of its policies. That argument speaks directly to the preservation of the state itself (including "acting quickly and decisively against threats, protecting sources and methods of intelligence gathering, and investigating and enforcing the law against violators). ${ }^{\prime 108}$ Second, secrecy may be necessary to permit frank and free "governmental deliberations and decision making," ${ }^{109}$ although, I would note, none of these deliberations, if known publicly, would necessarily amount to a state secret. Third, secrecy may be necessary to protect individual privacy or other associated values, which again do not necessarily involve state secrets. Finally, to keep things secret is seemingly cheaper than developing an administrative structure to promote and enact transparency policies. ${ }^{110}$

Taking this issue from a very different perspective, philosopher Bernard Williams mused that

If the right to spy [by the state] is granted at all, then the right to know must be suspended; or if it is insisted upon, then it queries must be met with lies. Espionage, one must tautologously insist, is supposed to be covert. There are indeed 
questions [...] about what sort of activity espionage is; what role it plays in national security; and what sorts of games, in the name of national security, are played between nations. But one thing that is clear is that so long as there are such activities, the more the right to know is insisted upon, the thicker the web of even domestic deceit must become. ${ }^{111}$

He is, of course, very perceptive.

Here, it would be fair to suggest that scholars have not spent a large amount of time and effort identifying and analyzing the sets of reasons that secret keepers or judges rely on not to disclose state secrets. While they have had no difficulty recognizing that state secrets can be considered legitimate, essentially pointing at consequentialist arguments, they have described and developed these arguments cursorily; there is no sense in their writings that these arguments are cogently connected to one another or that they form a coherent discourse reproduced by the community of secret keepers and judges.

\section{How are State Secrets Protected from Disclosure?}

Where the study of secrecy has particularly not been neglected, as I have noted above, is in its breach. Simmel captures very well why secrecy pledges are transgressed:

the possibility and the temptation of treachery plays around the secret, and the external danger of being discovered is interwoven with the internal danger of self-discovery, which has the fascination of the brink of a precipice. Secrecy sets barriers between men, but at the same time offers the seductive temptation to break through the barriers by gossip or confession. This temptation accompanies the psychical life of the secret like an overtone. Hence the sociological significance of the secret, its 
practical measure, and the mode of its workings must be found in the capacity or the inclination of the initiated to keep the secret to himself, or in his resistance or weakness relative to the temptation to betrayal. ${ }^{112}$

Accepting that state secrecy is bound to be violated, but that perhaps the initiated can resist temptation, suggests that criminology, sociology or law may have something to say about crimes related to the unauthorized disclosure of state secrets. Sébastien-Yves Laurent has shown in his review of the criminology literature that it does not have much to say on this, ${ }^{113}$ at least directly. The literature on sociology is in a similar situation. Just like criminology, it offers ideas, concepts and mechanisms (e.g., deterrence, social control, physical and socio-cultural restraints, habits, norms) to account for conformity and compliance, and these would be relevant to help explain why so many secret keepers abide by their oath of secrecy.

Essentially, the state relies on a broad assemblage of disciplinary and normalizing techniques ("heterogeneous, linked set of processes and techniques that seek to harness the raw power of information"114) to ensure that secret keepers abide by the law. Stanton Tefft summarizes them well:

These include secrecy classifications, screening and security clearances for potential employees, indoctrination, oaths of loyalty (sometimes), severe penalties for unauthorized disclosures, and continued surveillance of employees once hired ("aftercare"). Within the executive leadership only the most trusted officials may be privy to the totality of some secret plans or activities, while others know only small details rather than the whole picture. Still others gain access to certain details on a need-to-know basis. ${ }^{115}$ 
More specifically, secret keepers, in addition to acting lawfully, are expected to behave in accordance with a normative code of ethics, and to abide by the duty of loyalty they owe to the Constitution and their employer (the state and not an individual officeholder). The internalization of these values act as a form of self-regulation that may be important. The former director of the United Kingdom's Government Communications Headquarters, Sir David Omand, writes that:

self-regulation is the most important form of regulation [...] You can have all the rules and all the oversight, but when they are out of your sight, you have to rely on the fact that [your staff] have internalised a code of values. ${ }^{116}$

Greg Thielmann, who served with the Bureau of Intelligence and Research at the State Department, gives support to this view when he writes that:

As a 25-year veteran of the US Foreign Service, I was not a stranger to encounters with the public and with the press, but most of my work during those years was in the classified realm and most of my advice and analysis was for official consumption only. I had internalized a professional code of conduct designed to protect the sources and methods used to acquire intelligence secrets and to encourage frank and open policy deliberations inside government. I was concerned about inadvertently stepping over the line in discussing subjects dealing with classified information. ${ }^{117}$

But as Michael Waller and Andrew Linkater observe: "The idea that loyalty arises purely from sentiment, from a 'we-feeling' entirely independent of any manipulation or manufacturing, is surely naïve. ${ }^{118}$ So the state goes to great length to intimately know its secret keepers' past, associations to 
others (for example, criminals, antisocial individuals, foreign state actors...), and risk factors (for example, educational and employment failure, a criminal history, substance abuse...) in order to assess their future behavior. They accumulate that knowledge through extensive and detailed background or vetting investigations (the more intrusive the more sensitive the secrets to be accessed by a secret keeper are). But background investigations have not always been good indicators of future behaviors:

the effort is [...] to formulate a judgment about the degree of possibility that an event will occur in the future. The extent of the risk that a particular individual will be faithless is not subject to conclusive demonstration. A judgment concerning it involves hypotheses, impressions, experiences, and generalized prejudices (favorable or unfavorable to the applicant), which are brought to bear consciously or, often, unconsciously. ${ }^{119}$

Therefore, other mechanisms are also relied upon to ensure that secret keepers to do not disclose any state secrets without authorization. The first mechanism is about indoctrination and training. The benefits of properly training individuals were well captured centuries ago. James Urmson, in his interpretation of Aristotle's ethics, writes that:

If properly trained one comes to enjoy doing things the right way, to want to do things the right way, and to be distressed by doing things wrongly. [...] Aristotle compares acquiring a good character with acquiring a skill. [...] Before one has acquired the art or skill one acts in accordance with the instructions of a teacher, who tells us what to do, and one does it with effort. Gradually, by practice and repetition, it becomes effortless and second nature. ${ }^{120}$

Indoctrination, on the other hand, is more subtle. It involves things like rituals of initiation to a profession, the acquisition of a unique 
professional language, and processes of socialization and resocialization to classified environments. Jon Wiant discusses the first two mechanisms as follow:

Rituals of initiation: Institutional or "tribal" boundaries are maintained by the requirements of entry rituals, e.g. examinations, special screenings, polygraph, etc. The badges of the Community symbolically reaffirm the importance of the initiation ritual. [...] The more sensitive the collection sources/methods the more likely the organization involved takes on the attributes of a secret society or rigorously clan like organization. There is limited mobility between such clans and they all tend to develop unique professional language that requires some simultaneous translation at the boundaries. ${ }^{121}$

Former CIA intelligence analyst Aki Peritz explains at length how the socialization and resocialization processes work:

[CIA employees are] constantly reminded of the oath already. CIA employees are already acutely aware of what happens when you disclose classified material. From the first day a new agency trainee, analyst, or administrative staff member enters CIA Headquarters and 'takes the oath' to uphold and protect the US Constitution, they are told in no uncertain terms the very ugly, life destroying consequences of betraying privileged information. As a former analyst, I remember the gruff, mustachioed fellow from the Office of Security who, on the first day of my employment, made this point crystal clear.

This emphasis is underscored in multiple training classes. For example, every new analyst must attend the Career Analyst Program (CAP), where grizzled intelligence vets teach 'the basic thinking, writing, and briefing skills needed for a successful career.' One point that gets hammered home is what happens to people who provide information to those who shouldn't have it especially foreign governments. These classes highlight, among other cases, the Aldrich Ames and Robert Hanssen affairs, and take care to emphasize that these former top officials are currently serving life sentences in prison. 
It's the Agency Culture. CIA employees are reminded in ways both large and small about the consequences of mishandling or misusing classified documents. Your colleagues remind you. Your managers remind you. The internal websites remind you. When someone is caught providing secrets, even the director reminds you.

Furthermore, because of their chosen careers, CIA employees are made justifiably paranoid about 'security violations' for instance, if you absent mindedly took a classified document from your office, placed it in your briefcase or purse, exited the building, and then remembered you had it while walking to your car, the Office of Security could slap you with a security violation. (Pro tip: Don't take a suitcase or large purse to work.) ${ }^{122}$

These mechanisms can be very effective. Memoirs of former intelligence professionals often reflect on that point:

Miles Copeland: "The most impressive part of this initial CIA indoctrination is the attitude toward loyalty, security, precision, attention to detail, and healthy suspicion that it manages to implant in the minds of the trainee. 'Because of my indoctrination,' writes Patrick McGarvey in his CIA: The Myth and the Madness, 'I still get a visceral twinge - and have qualms of conscience about writing this book.' Although one cannot detect any signs of reticence in Pat McGarvey's book, I know what he means. The fact is that this aspect of the indoctrination has been designed by some of the nation's best psychologists, employing the most modern techniques of 'motivational research.' Certainly it achieves its purpose... Also, the psychologists believe their course imparts a strong sense of mission, which is lacking in other branches of government. ${ }^{123}$

Gail Donnalley: "This legal requirement [to protect intelligence sources and methods] is consciously and unconsciously instilled in each employee of the Central Intelligence Agency every day of his employment. For those of us who have been with the Agency for some time, protection of sources and methods has thus become instinctive. We have been trained to err on the side of caution, because a mistake the other way could have dire effects." ${ }^{124}$

Tyler Drumheller: "We had it drummed into us for so long: don't wave any red flags, don't talk about this or that, don't stand out. So 
you grow distant from your wider family and friends and grow closer to your agency friends." ${ }^{125}$

In spite of these and other similar testimonials, the state yet goes

further in ensuring that its secrets remain under wrap. As Seumas Miller explains, values, indoctrination and training are not sufficient in and of themselves:

From the fact that individual persons are inducted into a particular framework of conventions, social norms, institutions, and other social forms, and therefore exhibit the characteristic features and orientations of members of the social group in question, it does not follow that those individuals are not morally autonomous agents or that they are to any significant extent coerced. [...] it is a matter for empirical investigation whether some value has been imposed on a particular individual, or individuals, or not. ${ }^{126}$

The state therefore has another suite of mechanisms to minimize the risk of unauthorized disclosure. The first is establishment of need-to-know controls. Judge Richard Posner correctly explains the rationale for such controls:

It's [...] a mistake to think that simple possession of a security clearance automatically entitles its possessor to access to classified information that he is cleared to see. (The levels of classification differ; someone cleared for Secret information is not entitled to access to Top Secret information.) There are too many leaks of classified information-too much carelessness and irresponsibility in the handling of such information-to allow automatic access to holders of the applicable security clearances. [...] So in addition to having the requisite clearance the seeker must convince the holder of the information of the seeker's need to know it. ${ }^{127}$

If no one knows too much, then the damages resulting from unauthorized disclosures can be minimized, so the logic goes. To ensure that 
no one knows more than strictly necessary to carry out one's duties, classified information is compartmentalized, that is, it is sliced "into parts so no one individual can put the secrets together to comprehend a 'bigger picture."'128 Such compartmentalization has the added advantage of making a secret keeper "a less savory target for those who seek to know the full picture. ${ }^{129}$ Memoirs of former intelligence officers discuss this process in some details. For example, Ralph Bennet, a direct participant in this process at the United Kingdom's Government Code and Cipher School during World War II, recalls,

[...] there was the necessary restriction imposed by our own security regulations upon the use of Ultra [German intercepted communications]. The number of those allowed to know about it was strictly limited both at home and in the field. Commanders were strictly forbidden to order any action which might imperil the source by seeming to be ascribable only to the reading of Enigma traffic-[...] unless it was diluted from less secret sources, the consequences might be disastrous-it might be compromised and so lost for the future. [...] The number of those in the secret was kept to the minimum compatible with effective use. ${ }^{130}$

Compartmentalization, however, has disadvantages. As Walter

Gellhorn explains:

The inefficiency of compartmentalization of work-or, more accurately, fragmentation of knowledge-is threefold. First, fragmentation so narrows the range of expertness that effective utilization of scientifically trained manpower is badly hampered. [...] Second, compartmentalization prevents full utilization of work that has already been successfully accomplished. [...] Third, compartmentalization necessitates frequent duplication of unfruitful research. ${ }^{131}$ 
The second mechanism requires secret keepers to accept prior restraint and to sign nondisclosure agreements. As Jack Balkin explains:

\begin{abstract}
A prior restraint is a licensing system, in which a censor (either the state or a private party) decides whether speech will be permitted at all. Subsequent punishment is a system of prosecutorial discretion, in which the state or a private plaintiff decides whether it is worth undertaking the costs of prosecution or litigation. Systems of prior restraint create bottlenecks with fewer procedural protections. They place the burden on the speaker to gain permission, and therefore the power of inertia rests with the censor, who may delay or simply decide against publication as a matter of administrative convenience. Having to ask permission alerts the censor to what is being published and establishes the idea of censorship as a norm. Moreover, if a speaker does not seek permission or tries to route around the system, retribution is likely because the speaker has specifically defied the authority of the censor. 132
\end{abstract}

In the United States, federal employees are bound to secrecy for life by agreeing never to divulge classified information without explicit authorization from the executive branch. ${ }^{133}$ Before being granted access to classified information, President Reagan, in his National Security Decision Directive 84 of 11 March 1983, further required federal employees to sign a nondisclosure agreement that would be binding and enforceable through disciplinary measures or in a civil action. ${ }^{134}$ For those employees having access to Sensitive Compartmented Information (SCI), in particular all employees of the Central Intelligence Agency, the additional obligation, during the course of employment and thereafter, to submit to the employing department all information and material, including work of fiction, intended for publication, was imposed. ${ }^{135}$ 
Veteran CIA officers are conscious of this obligation. Gary Schroen writes that:

One of the challenges facing every CIA officer who sits down to write anything for publication, regardless of the format or length, is the requirement to protect the secrecy of CIA sources and methods. This responsibility is spelled out in a formal secrecy agreement that each CIA officer signs as part of his initial employment processing. The agreement also includes a requirement that any and all materials written for publication must be submitted to the CIA's Publication Review Board (PRB), with the aim of editing out any classified information or any sensitive operational details that might jeopardize methods used in the field, identify specific foreign nationals serving as sources for the CIA, or identify CIA officers serving undercover. ${ }^{136}$

The third mechanism is the conduct of regular polygraph examinations throughout the career of those collecting and accessing the most sensitive information. These examinations have a long history in the United States (the CIA, for example, started using the polygraph for the screening of potential employees as early as 1947). ${ }^{137}$ The objective of these examinations is primarily to act as deterrent by ensuring commitment to one's obligations. ${ }^{138} \mathrm{~A}$ young US military intelligence soldier tells of her polygraph experience as follow:

I sit in the polygraph chair before training can start, heart pounding as I'm strapped, fingers and heart, to a machine that reads my every flutter and gasp. Top-secret starts here, with these last few tests, to make sure I'm not a traitor or a liar. And when I pass, when this next level of training starts, I learn there is a sequester of knowledge. ${ }^{139}$

Former CIA covert case officer Valeri Plame Wilson, upon the start of yet another polygraph examination, approached it as follow: 
Although my initial poly had not been painful, it is an experience that no one ever likes. This time, however, I approached the dreaded exam armed with a colleague's advice: treat it like a Catholic confession. That is, tell the examiner absolutely everything, every excruciating detail that you think might have relevance to the question posed. At a minimum, you'll bore the polygrapher to tears. I used this tactic, dredging up every possible incident that might negatively affect my responses and it worked like a charm; I was in and out of the claustrophobic exam room in a record three hours. ${ }^{140}$

The polygraph too, however, is not infallible. As neuroscientist James Fallon notes,

Most people with a conscience have tells that betray their thoughts and emotions. That's why most people are poor poker players. But psychopaths are masters at hiding their true intentions. One of their disarming but pernicious attributes is their ability to remain cool when they lie. [...] psychopaths can dream up fantastic lies and never show any sign of guilt or remorse. Some psychopaths [however] do respond emotionally, as measured by heart rate and galvanic skin response $[\ldots] .{ }^{141}$

Additional mechanisms are therefore applied, including a wide range of measures affecting situational factors. In criminology, Situational Crime Prevention (SCP) is an approach that seek to to minimize the risk of occurrence and the seriousness of a crime ${ }^{142}$ by increasing the effort required to commit a crime, increasing the risks for a potential offender, reducing the reward derived from crime, reducing provocation and removing excuses for committing a crime. ${ }^{143}$ In the context of state secrecy, this means specific protection measures to avoid the unauthorized access to secrets and the detection of inappropriate use of secrets including special physical standards, the use of Secure Compartmentalized Information Facilities (SCIF), biometric 
identifiers, the prohibition of personal electronic devices where secrets can be assessed, the physical surveillance of premises where secrets are located, the constant monitoring of computer use, and random physical personal searches on work premises. As the young US military intelligence soldier quoted above observed:

I now exist in places carefully monitored and structured for security, enclosed rooms with no windows, no cell phones or internet, these Sensitive Compartmented Information Facilities where anything can be said and everywhere else outside these doors is profane. ${ }^{144}$

As no single mechanism is sufficient to protect state secrets from unauthorized disclosure, the state relies instead on a broad assemblage of disciplinary and normalizing techniques, which together significantly minimize the risks of disclosures. Trust in this context is the last line of defense:

It is [...] important to note that while all of our capabilities can reduce the likelihood and impact of unauthorized disclosures, in the final analysis our system is based on trust-trust in the individuals who have access to classified information and trust that they will be responsible stewards of this Nation's most sensitive information. ${ }^{145}$

\section{Conclusion}

This literature overview has shown that secrecy is pervasive in society and constitutive of the material nature of state power. In a post-9/11 context, claims of state secrecy have been increasingly normalized. A secret, it has been shown, is more than information or material that the state is 
taking measures to safeguard because of consequentialist reasons. It is also a social construct. Its very content (whether it has any value) is covered, isolated or disguised through symbolic and ritualistic practices, without which there would be no revelation possible. ${ }^{146}$ It has a political life as much as it affects individual and group identities because of its symbolic value. But it also has a formal, legal existence as it is subject to laws adopted by competent authorities.

These laws and rules make it a crime to disclose a state secret without authorization. To prevent such disclosure, the law, including the harsh law of treason, supposedly serves as a deterrent. However, as deterrence does not always work, the law is supplemented by a series of social and physical controls to reduce the temptation and the very possibility of secret keepers transgressing the law. The law, in legal proceedings, allows the state to refer to provisions and procedures that, when correctly applied, protect state secrets from legal disclosure.

The literature on state secrecy, to the extent one can be identified, is disparate, largely US-centric, but also multidisciplinary, and on the ascendency. As many of the questions surrounding social and state secrecy have been answered in many different ways by a plurality of scholars, there is a question that is calling for answers just as secrecy is being normalized: What sets of reasons or rationalities do secret keepers and the law use to justify the nondisclosure of state secrets? The legal environment is a prime 
site for such an investigation because it is there that these reasons are best articulated, either in written documents or in oral arguments. The gap in the literature on state secrecy is about what is said on why state secrets deserve protection from disclosure, by whom, and with what effect. This is ultimately about how the discourses of secret keepers and the law legitimize the existence of state secrets. Without knowing how state secrecy claims are justified through discourse, a discourse of resistance cannot be properly articulated and deployed and the current construct of state secrecy changed. De Lint and Pozen, with his consequentialist arguments, have started the analysis, but it remains limited to a number of paragraphs. The time is ripe to move the literature forward in a way that will contribute and complement its development a developing literature at a time of abundant state secrets. ${ }^{147}$

\section{Notes}


${ }^{1}$ Carson, "Review of Robert Mandel's Global Data Shock," 5.

${ }^{2}$ Neuberger, "Is Nothing Secret?"

${ }^{3}$ Schwarz, Democracy in the Dark, 2, 5.

${ }^{4}$ Arnold, Secrecy in the Sunshine Era, xii.

${ }^{5}$ Sagar, Secrets and Leaks, 3.

${ }^{6}$ Ibid, 5.

${ }^{7}$ Ibid, 7.

${ }^{8}$ Lester, When Should State Secrets Stay Secret?, 6.

${ }^{9}$ Colaresi, Democracy Declassified, 5.

${ }^{10}$ Ibid.

${ }^{11}$ González, "Anthropology and the Covert," 21-22. "[...] social science has little interest in the secrecy systems related to the internal politics of complex organizations. Their disregard of the role of information control within such bureaucracies is in marked contrast to their fascination with the secrecy process within small-scale organizations such as secret orders or associations." Tefft, "Secrecy, Disclosure and Social Theory," 60. Erickson and Flynn agree with Tefft: "[...] secrecy has rarely received attention within the field of complex organizations. Theoretical perspectives do not include it as a major construct useful for understanding organizational behavior. Research that examines its role in organizational settings is almost non-existent." Erickson and Flynn, "Secrecy as an Organizational Control Strategy," 251. On secrecy, secret societies and the occult, see, inter alia, Roberts, The Mythology of the Secret Societies, Gunn, Modern Occult Rhetoric, Coignard, Un État dans l'État, and Bratich, "Popular Secrecy and Occultural Studies." For an overview of the literature on religion and secrecy, see Duncan, "Religion and Secrecy." Notwithstanding, Urban has argued that, "To date, the study of secrecy and new religions - and indeed, the study of religious secrecy in general - remains surprisingly under-developed and poorly theorized." Urban, "Secrecy and New Religious Movements," 67.

${ }^{12}$ Urban, "The Torment of Secrecy," 212-213.

13 Lowry, "Toward a Sociology of Secrecy and Security Systems," 298.

${ }^{14}$ Balmer, Secrecy and Science, 2. As Walters and Luscombe note: "Secrecy is a curiously neglected mediator of power/knowledge relations and an under-studied factor in politics within the growing field of IPS. In the wider field of political science, there have been periodic attempts to theorize political secrecy. That said, and despite some important interventions [...], political secrecy has not been accorded anything like the depth of critical attention devoted to such questions as sovereignty, the public sphere, or citizenship." Walters and Luscombe, "Hannah Arendt and the Art of Secrecy," 7.

${ }^{15}$ The push for a field and a dedicated journal is largely the work of Susan Maret. See her "The Charm of Secrecy," and "Introduction: Government Secrecy." With Goldman, she edited the only set of readings on government secrecy. See Maret and Goldman, eds., Government Secrecy: Classic and Contemporary Readings.

${ }^{16}$ See Secrecy and Society, "About" at

https://scholarworks.sjsu.edu/secrecyandsociety/about.html

${ }^{17}$ Erickson and Flynn, "Secrecy as an Organizational Control Strategy," 252. The large contemporary literature on espionage is a case in point.

18 See, inter alia, Elias, ed., Deviant and Criminal Behavior in the Workplace.

${ }^{19}$ Griffin and Lopez, "When Employees Turn Violent," 200.

${ }^{20}$ Sources are extensive and well covered. The most comprehensive literature review of espionage and intelligence is Oleson, ed., AFIO's Guide to the Study of Intelligence. See also, inter alia, Andrew, Aldrich and Wark, eds., Secret Intelligence, Calder, ed., Intelligence, Espionage and Related Topics, Carlisle, Encyclopedia of Intelligence and Counterintelligence, Clark, Intelligence and National Security, Constantinides, Intelligence and Espionage, Dover, Goodman and Hillebrand, eds., Routledge Companion to Intelligence Studies, and Johnson and Wirtz, eds., Intelligence: The Secret World of Spies.

${ }^{21}$ Counterintelligence is about protecting one's own intelligence from adversaries by identifying their spies and techniques of collection and disrupting them. Taylor, "Definitions and Theories of Counterintelligence," 5-8.

${ }^{22}$ For a discussion on NGrams, see Rosenberg, "Data before the Fact," 15. 
${ }^{23}$ Michel Shen, Aiden, Gray, Brockman, Google Books Team, Pickett, Hoiberg, Dan Clancy, Peter Norvig, Jon Orwant, Steven Pinker, Martin A. Nowak \& Erez Lieberman Aiden. "Quantitative Analysis of Culture Using Millions of Digitized Books." Science 331, no. 6014 (2011): 176-182. ${ }^{24}$ Thompson, "Democratic Secrecy," 181-182.

${ }^{25}$ Birchall, "Transparency, Interrupted," 67.

${ }^{26}$ Highmore, Ordinary Lives, 15.

${ }^{27}$ Feinberg, Freedom and Fulfillment, 133.

${ }^{28} \mathrm{Simmel}$, interested in forms of human interaction, looked at the role of secrecy in social organization through a study of secret societies. Simmel, "The Sociology of Secrecy and of Secret Societies."

${ }^{29}$ Goffman, The Presentation of Self in Everyday Life, and Goffman, Behavior in Public Places.

${ }^{30}$ Miller, Faking It.

${ }^{31}$ Moss, "Secrecy," 4140. The standard reference in this line of inquiry is Bok, Secrets.

${ }^{32}$ Simmel, "The Sociology of Secrecy and of Secret Societies," 462.

${ }^{33}$ Ibid.

${ }^{34}$ According to the literature review of Kumar, Martin and Bray, "Secrecy, Law and Society," 9.

${ }^{35}$ On suppressing relations: Lane and Wegner argue that secrecy is "rather an antisocial act, in the sense that it is targeted toward some audience to whom the truth is to be denied." Lane and Wegner, "The Cognitive Consequences of Secrecy," 237.

${ }^{36}$ Deleuze and Guattari, A Thousand Plateaus, 286-287.

${ }^{37}$ Ibid, 287.

38 Costas and Grey, "Bringing Secrecy into the Open," 1426.

${ }^{39}$ Ibid, 1429.

${ }^{40}$ Noted by Urban, "The Adornment of Silence," 3.

${ }^{41}$ Brodie, "Learning Secrecy in the Early Cold War," 652. Anthropologists too have recognized the inclusion-exclusion effects of secrecy: "Possession differentiates. Concealed information separates one group from another and one person from the rest. What I know and you do not demonstrates that we are not identical, that we are separate people. The difference can create a hierarchy, wherein secrecy cedes social power to those who control the flow of treasured information." Luhrmann, "The Magic of Secrecy," 137. So did sociologists. In particular, this effect was recognized by sociologist Simmel, who argued that those who share secret knowledge develop trust and affective bonds between themselves; they develop a sense of cohesion as they are secluded against the outside of their secret society. Simmel, The Sociology of Georg Simmel, 348, 369, and Simmel, Sociology, 337.

${ }^{42}$ Quoted by Sissman, John Le Carré, 184.

${ }^{43}$ Davenport-Hines, ed., Hugh Trevor-Roper, 149.

${ }^{44}$ Debord, Comments on the Society of the Spectacle, section V. Debord defines the spectacle as follow: "Understood in its totality, the spectacle is both the outcome and the goal of the dominant mode of production. It is not something added to the real world - not a decorative element so to speak. On the contrary, it is the very heart of society's real unreality. In all its specific manifestations - news or propaganda, advertising or the actual consumption of entertainment the spectacle epitomizes the prevailing model of social life. It is the omnipresent celebration of a choice already made in the sphere of production, and the consummate result of that choice. In form as in content the spectacle serves as total justification for the conditions and aims of the existing system. It further ensures the permanent presence of that justification, for it governs almost all time spent outside the production process itself." Debord, The Society of the Spectacle, 13.

${ }^{45}$ Debord, Comments on the Society of the Spectacle, section XVIII.

${ }^{46}$ Ibid, section VIII.

${ }^{47}$ Ibid, section IX.

${ }^{48}$ Ibid, section XXI.

${ }^{49}$ McCraw and Gikow, "The End to an Unspoken Bargain?" 480.

${ }^{50}$ Simmel, "The Sociology of Secrecy and of Secret Societies," 463.

51 Dean, "Secrecy Since September 11," 368.

52 Ibid. 
Lefebvre: State Secrecy: A Literature Review

${ }^{53}$ Ibid, 369.

54 Ibid.

${ }^{55}$ Masco, The Theater of Operations, 138.

${ }^{56}$ Ibid.

${ }^{57}$ Mewett, "State Secrets in Canada," 358-359; Hogg, Monahan and Wright, Liability of the Crown, 10,24 . The qualifier "state" refers to the notion that the rules of state secrecy extends beyond government to include entities such as the legal and parliamentary systems.

${ }^{58}$ A Canadian Treasury Board Secretariat policy states that: "When information is classified in the national interest, a further judgment is needed to determine the classification level. The level depends on the gravity of the detrimental effects that might reasonably be expected to occur from compromise. The levels of classification are as follows: - Top secret: applies to the very limited amount of information that, if compromised, could reasonably be expected to cause exceptionally grave injury to the national interest; - Secret: applies to information that, if compromised, could reasonably be expected to cause serious injury to the national interest; - Confidential: applies when compromise could reasonably be expected to cause injury to the national interest." Treasury Board Secretariat, Security Organization and Administration Standard.

${ }^{59}$ Shapiro and Siegel, "Is this Paper Dangerous?" 75.

${ }^{60}$ In Westminster-type parliamentary systems, Cabinet proceedings and decisions are treated as confidential in the interests of good government for a period of time that may vary depending on the nature of the information and the public interest in disclosure. Cabinet ministers are subject to a convention of joint Cabinet responsibility and their individual position on any decision is not meant to be disclosed, so as not to allow political opponents to "exploit such information to undermine the unity of the government and hence its ability to maintain the confidence of the House of Commons." d'Ombrain, "Cabinet Secrecy," 335. In the United Kingdom, the issue of Cabinet confidentiality and its extent reached the court for the first time in Attorney General $v$ Jonathan Cape Ltd [1976] QB 752 (Lord Widgery CJ) wherein the publication of a minister's diary of Cabinet proceedings was in dispute. Lord Widgery $\mathrm{CJ}$ concluded that the court had the power to interdict the publication of Cabinet confidences by a minister if the minister received this information in confidence as long as the Attorney General can demonstrate "(a) that such publication would be a breach of confidence; (b) that the public interest requires that the publication be restrained, and (c) that there are no other facets of the public interest contradictory of and more compelling that that relied upon." Excerpt of Attorney General $v$ Jonathan Cape Ltd [1976] QB 752 (Lord Widgery CJ) in Turpin and Tomkins, British Government and the Constitution, 153. Lord Widgery added, however, that Cabinet confidentiality will lapse at a certain point, for instance when it could no longer affect Cabinet proceedings.

${ }^{61}$ National Security Counselors v Central Intelligence Agency, 188.

${ }^{62}$ Costas and Grey, "Bringing Secrecy into the Open," 1431.

${ }^{63}$ Scheppele, Legal Secrets, 21-22, 75-79, 84-85. A full discussion of this distinction can be found in Pozen, "Deep Secrecy." He correctly notes that, "the depth of a secret is not necessarily a binary feature; rather, depth is determined by a variety of interrelated factors, according to which any particular secret may be located on a continuum running from maximally opaque to maximally intelligible. Cutoffs may be made along the continuum, but criteria must be developed to do so - and even still, complications will inevitably arise in the application of general standards to a phenomenon as vast and heterogeneous as secrecy. "Deep" and "shallow" can serve profitably as proxies, or heuristics, for the rough location of a secret on the continuum. But it is a conceptual mistake to see them as wholly discontinuous categories." Ibid, at 266.

64 Goldman and Maret, Intelligence and Information Policy, 505-506. Also see a previous work by Maret (2011).

65 See also Maret, "Introduction."

66 Bentham, in Engelmann, ed., Selected Writings by Jeremy Bentham, 302; noted by Schofield, Utility and Democracy, 270. Although Bentham devised a theory and a plan for the organization of government that remained prescient for what was to follow-see the discussions of Bentham's work on the modern state by Hume, Bentham and Bureaucracy, and Rosenblum, Bentham's 
Theory of the Modern State - his discussion of secrecy remained somewhat unproblematized and undertheorized; it was utilitarian, reflecting the driving factor of his life's work. His argument on publicity in parliamentary proceedings extended to the open court principle. See the discussion in Resnik, "Bring Back Bentham."

67 Spinoza, Tractatum Theologico-Politicus, 342.

68 Spinoza, "Political Treatise," 341, quoted by Sánchez Estop, "Wikileaks," 44.

69 Waldron, "Hobbes and the Principle of Publicity," 182, 185, 187. Hobbes's famous statement on publicity is at Hobbes, Leviathan, 231-232.

${ }^{70}$ Mill, On Liberty, 213-310. Noted by Bisman, "Personal Information and the Professional Relationship," 19.

71 Neocleous, "Privacy, Secrecy, Idiocy," 89.

72 Ibid, 96.

${ }^{73}$ Ibid, 89, 92, 94, 98.

74 Ibid, 99.

${ }^{75}$ Weber, "Bureaucracy," 116-117.

${ }^{76}$ Weber, "Parliament and Government in Germany under a New Political Order," 179.

${ }^{77}$ Weber, "Bureaucracy," in Gerth and Mills, eds., 233.

${ }^{78}$ Weber, "Parliament and Government in Germany under a New Political Order," 185.

${ }^{79}$ Ibid, 186.

${ }^{80}$ See Moynihan, Secrecy and Commission on Protecting and Reducing Government Secrecy, Report.

${ }^{81}$ Offe, "The Theory of the Capitalist State and the Problem of Policy Formation," 127, as discussed by Barrow, Theories of the State, 101. See also Hunt, "Marxism, Law, Legal Theory and Jurisprudence," 102.

82 "The bureaucracy is a magic circle from which no one can escape. Its hierarchy is the hierarchy of knowledge [...]. The bureaucracy holds the state, the spiritual essence of society, in thrall, as its private property. The universal spirit of bureaucracy is secrecy"; See Marx, "The Critique of Hegel's Doctrine of the State," 107, quoted by Allen, Max Weber, 148 and Pels, Property and Power in Social Theory, 194. Also translated as "The general spirit of bureaucracy is the official secret, [...]" in Marx, "Critique of Hegel's Philosophy of Right," 185.

83 Allen, Virginia Woolf and the Politics of Language, 3.

${ }^{84}$ Peters, The Politics of Bureaucracy, 309.

${ }^{85}$ Robinson, "Bureaucracy," 43.

${ }^{86}$ Emerson, "The Danger of State Secrecy," 398.

${ }^{87}$ Reed, "Beyond the Iron Cage?" 122.

88 "Increasingly, intelligence that would not be accepted in court as evidence serves as the basis for a broad range of administrative practices, which De Goede defines as an extra-legal field of intervention." Bonelli and Ragazzi, "Low-tech security," 479.

89 "The fodder of CSIS [Canadian Security Intelligence Service] investigations-intelligence product consumed by policy makers-is now increasingly converted into evidence in court proceedings, including in criminal prosecutions." Forcese, "The Judicialization of Extraterritorial Spying," 440-441.

90 De Lint, "Intelligent Governmentality," 281.

91 In his history of madness, Foucault identified forms of exclusion that shifted alongside other transformations. He saw exclusion as a means of social control against lepers, the poor, the vagrant, the criminal, the alienated, etc. Foucault, History of Madness. He developed this approach to study history further in his L'archéologie du savoir.

92 De Lint, "Intelligent Governmentality," 289.

${ }^{93}$ See, inter alia and in a Canadian context, Kinsman, Buse and Mercedes Steedman, eds., Whose National Security?, Kinsman and Gentile, The Canadian War on Queers, Whitaker and Marcuse, 
Cold War Canada, Hannant, The Infernal Machine, Kealey, "The Surveillance State," Kealey, "The Early Years of State Surveillance of Labour and the Left in Canada," Whitaker, "Origins of the Canadian Government's Internal Security System," and Whitaker, "Cold War Alchemy."

94 "Pre-crime [...] shifts the temporal perspective to anticipate and forestall that which has not yet occurred and may never do so. In a pre-crime society, there is calculation, risk and uncertainty, surveillance, precaution, prudentialism, moral hazard, prevention and, arching over all these, there is the pursuit of security." Zedner, "Pre-crime and post-criminology?" 262. This further involves legislation operationalized through police and security agencies. McCulloch and Pickering, "Counter-terrorism," 13. Intelligence in this context is considered vital. Ibid at 16. 95 Which "can best be expressed as a continuing concern with the minimizing of bads against goods - and by extension the safeguarding of elite interests." Rigakos and Hadden, "Crime, capitalism and the 'risk society'," 73. Risk assessment techniques and tools in the area of (national) security are heavily reliant on intelligence gathering, whose sources and methods are protected from public disclosure.

${ }^{96}$ Dean, Governmentality, 8.

${ }^{97}$ In matters of national security, Canadian courts have usually shown deference to the executive branch because, as Supreme Court Justice Binnie publicly noted, security agencies "have more expertise information and resources on such matters than the courts." As reported by the Communications Security Establishment Commissioner in his Annual Report 2004-2005, 16. It is only the state which is in a position to create an official viewpoint that must be recognized by the court. Bourdieu, Sur l'État, 95.

${ }^{98}$ De Lint and Virta, "Security in Ambiguity," 474.

${ }^{99}$ Bourdieu, Sur l'État, 95.

100 Scheppele, Legal Secrets, 323. See also Hamilton, "Speaking Prose All Along."

${ }^{101}$ Gutmann and Thompson, Democracy and Disagreement, chapter 3.

102 Ibid, 101.

${ }^{103}$ Ibid, 105.

${ }^{104}$ Ibid.

${ }^{105}$ Ibid, 114-115.

${ }^{106}$ Ibid, $117-118$.

107 Ibid, 121.

108 Pozen, "Deep Secrecy," 277.

109 Ibid.

${ }^{110}$ Ibid.

${ }^{111}$ Williams, Essays and Reviews 1959-2002, 163-164.

112 Simmel, "The Sociology of Secrecy and of Secret Societies," 466.

${ }^{113}$ Laurent, "Travailler sur «l'État secret» contemporain," 264-265.

${ }^{114}$ The short quotation is from Cohen, Configuring the Networked Self, 137.

${ }^{115}$ Tefft, "Secrecy, Disclosure and Social Theory," 62.

${ }^{116}$ United Kingdom, Intelligence and Security Committee of Parliament, "Privacy and Security," 76.

${ }^{117}$ Thielmann, "From Intelligence Analyst to 'Citizen Watchdog'," 45.

118 Waller and Linklater, "The Changing Face of Political Loyalty," 230.

119 Gellhorn, Security, Loyalty, and Science, 90.

120 Urmson, Aristotle's Ethics, 26.

${ }^{121}$ Wiant, "The Anthropology of Intelligence," 10-11.

122 Peritz, "The CIA Doesn't Need a 'Glorious Loyalty Oath Crusade' to Keep Secrets."

${ }^{123}$ Copeland, Without Cloak or Dagger, 263-264.

124 Donnalley, "Declassification in an Open Society," 11.

${ }^{125}$ Drumheller, On the Brink, 190. 
${ }^{126}$ Miller, Social Action, 48, 50.

127 United States v. Daoud, 755 F(3d) 479, 484 (7th Cir 2014).

${ }^{128}$ Dufresne and Offstein, "On the Virtues of Secrecy in Organizations," 103.

${ }^{129}$ Ibid, 104.

${ }^{130}$ Bennett, ULTRA in the West, 22.

${ }^{131}$ Gellhorn, Security, Loyalty, and Science, 40-41.

132 Balkin, "Room for Maneuver," 92-93.

133 Fisher, "Congressional-Executive Struggles Over Information," 89.

134 Ibid, 90.

135 Ibid, 91.

${ }^{136}$ Schroen, First In, xi.

${ }^{137}$ National Security Counselors et. al. v. Central Intelligence Agency et. al., 70.

${ }^{138}$ Kaiser, "Secrecy, Intelligence, and Community," 285.

139 Dostie, Formation, E-book version chapter entitled "Redacted."

${ }^{140}$ Wilson, Fair Game, 53.

${ }^{141}$ Fallon, The Psychopath Inside, 215.

${ }^{142}$ Hayward, "Situational Crime Prevention and its Discontents," 235.

${ }^{143}$ Brantingham, Brantingham and Taylor, "Situational Crime Prevention," 276.

${ }^{144}$ Dostie, Formation, E-book version chapter entitled "Redacted."

145 Stone, Testimony Before Congress, 10.

${ }^{146}$ Hildesheimer has noted too that a state secret may have no intrinsic value and be nothing more than an anecdote, and that to know a secret involves that it be unveiled. "La connaissance historique a posteriori du secret, comme sa divulgation en son temps, passe à travers le dévoilement de sa mise à mots. [...] Il faut en effet préciser que tout écrit dit « secret » n'a pas forcément qualité à contribuer à cette histoire, car secret peut alors simplement rimer avec anecdote." Hildesheimer, "Le secret de l'État « moderne »," 11.

${ }^{147}$ My own efforts in this direction are captured in Lefebvre, "Why Are State Secrets Protected from Disclosure?" and Lefebvre, "What Do Judges Say on the Protection of Intelligence Secrets?."

\section{Bibliography}

Allen, Judith. Virginia Woolf and the Politics of Language. Edinburgh: Edinburgh University Press, 2010.

Allen, Kiern. Max Weber: A Critical Introduction. London: Pluto, 2004.

Andrew, Christopher, Richard J. Aldrich, and Wesley K. Wark, eds. Secret Intelligence: A Reader. 2nd ed. London: Routledge, 2020.

Arnold, Jason Ross. Secrecy in the Sunshine Era: The Promise and Failures of US Open Government Laws. Lawrence: University Press of Kansas, 2014.

Balmer, Brian. Secrecy and Science: A Historical Sociology of Biological and Chemical Warfare. Farnham: Ashgate, 2012.

Balkin, Jack M. "Room for Maneuver: Julie Cohen's Theory of Freedom in the Information State," Jerusalem Review of Legal Studies 6, no. 1 (2012): 79- 
95.

Barrow, Clyde W. Theories of the State: Marxist, Neo-Marxist, Post-Marxist. Madison: The University of Wisconsin Press, 1993.

Bennett, Ralph. ULTRA in the West: The Normandy Campaign of 1944-45. New York: Charles Scribner's Sons, 1980.

Bentham, Jeremy. "Of Publicity." In Selected Writings by Jeremy Bentham, edited by Stephen G. Engelmann, 291-307. New Haven: Yale University Press, 2011.

Birchall, Clare. "Transparency, Interrupted: Secrets of the Left." Theory, Culture \& Society 28, no. 7-8 (2011): 60-84.

Bisman, Cynthia. "Personal Information and the Professional Relationship: Issues of Trust, Privacy and Welfare." In Private and Confidential? Handling Personal Information in Social and Health Services, edited by Chris Clark and Janine McGhee, 17-34. Bristol: Policy Press, 2008.

Bok, Sissela. Secrets: On the Ethics of Concealment and Revelation. New York: Pantheon Books, 1983.

Bonelli, Laurent, and Francesco Ragazzi. "Low-Tech Security: Files, Notes, and Memos as Technologies of Anticipation." Security Dialogue 45, no. 5 (2014): 476-93.

Bourdieu, Pierre. Sur l'État: Cours Au Collège de France 1989-1992. Paris: Seuil, 2012.

Brantingham, Patricia L., Paul J. Brantingham, and Wendy Taylor, "Situational Crime Prevention as a Key Component in Embedded Crime Prevention," Canadian Journal of Criminology and Criminal Justice 47, no. 2 (2005): 271-292.

Bratich, Jack Z. "Popular Secrecy and Occultural Studies." Cultural Studies 21, no. 1 (2007): 42-58.

Brodie, Janet Farrell. "Learning Secrecy in the Early Cold War: The RAND Corporation." Diplomatic History 35, no. 4 (2011): 643-70.

Calder, James D., ed. Intelligence, Espionage and Related Topics: An Annotated Bibliography of Serial Journal and Magazine Scholarship, 1844-1998. Westport: Greenwood Press, 1999.

Canada. "Security Organization and Administration Standard." Treasury Board Secretariat, 1995. http://www.tbs-sct.gc.ca/pol/doc-eng.aspx? $\underline{i d=12333 \& \text { section }=\text { text }}$ 
Carlisle, Rodney P. Encyclopedia of Intelligence and Counterintelligence. New York: Sharpe Reference, 2005.

Carson, Austin. "Review of Robert Mandel's Global Data Shock: Strategic Ambiguity, Deception, and Surprise in an Age of Information Overload, HDiplo, ISSF Roundtable XI-13 (2020): 5-7.

Clark, J. Ramson. Intelligence and National Security: A Reference Handbook. Westport: Praeger Security International, 2007.

Coady, C. A. J. "Dirty Hands." In A Companion to Contemporary Political Philosophy, Volume 1, edited by Robert E. Goodin, Philip Pettit, and Thomas Pogge, 2nd ed., 532-40. Oxford: Blackwell, 2007.

Cohen, Julie E. Configuring the Networked Self: Law, Code and the Play of Everyday Practice. New Haven: Yale University Press, 2012.

Coignard, Sophie. Un État Dans l'État: Le Contre-Pouvoir Maçonnique. Paris: Seuil, 2009.

Colaresi, Michael P. Democracy Declassified: The Secrecy Dilemma in National Security. Oxford: Oxford University Press, 2014.

Cole, David. "The Three Leakers and What to Do About Them." The New York Review of Books LXI, no. 2 (2014): 7-9.

Commission on Protecting and Reducing Government Secrecy. Report of the Commission on Protecting and Reducing Government Secrecy. Senate Document 105-2. United States Senate, 105rd Congress, first session, Washington, D.C., Government Printing Office, March 3, 1997. https://www.govinfo.gov/app/details/GPO-CDOC-105sdoc2/summary

Communications Security Establishment Commissioner. Annual Report 20042005. Minister of Public Works and Government Services Canada, 2005.

Constantinides, George C. Intelligence and Espionage: An Analytical Bibliography. Boulder: Westview Press, 1983.

Copeland, Miles. Without Cloak or Dagger. New York: Simon \& Schuster, 1974.

Costas, Jana, and Christopher Grey. "Bringing Secrecy into the Open: Towards a Theorization of the Social Processes of Organizational Secrecy." Organization Studies 35, no. 10 (2014): 1423-47.

Davenport-Hines, Richard, ed. Hugh Trevor-Roper: The Wartime Journals. London: I. B. Tauris, 2014. 
De Spinoza, Benedict. The Chief Works of Benedict De Spinoza. London: George Bell \& Sons, 1891.

Dean, Jodi. "Secrecy Since September 11." Interventions 6, no. 3 (2004): 36280.

Dean, Mitchell. Governmentality: Power and Rule in Modern Society. Second. Los Angeles: Sage Publications, 2010.

"The Signature of Power." Journal of Political Power 5, no. 1 (2012): 101-17.

Debord, Guy. Comments on the Society of the Spectacle. London: Verso, 1991.

. The Society of the Spectacle. New York: Zone Books, 1995.

Deleuze, Gilles, and Félix Guattari. A Thousand Plateaus: Capitalism and Schizophrenia. Minneapolis: University of Minnesota Press, 1987.

Donnalley, Gail F. "Declassification in an Open Society," Studies in Intelligence 18, no. 3 (1974): 11-8.

Dostie, Ryan Leigh. Formation: A Woman's Memoir of Stepping Out of Line. New York: Grand Central Publishing, 2019. E-book version.

Dover, Robert, Michael S. Goodman, and Claudia Hillebrand, eds. Routledge Companion to Intelligence Studies. London: Routledge, 2014.

Drumheller, Tyler, with Elaine Monaghan. On the Brink: An Insider's Account of How the White House Compromised American Intelligence. New York:

Carroll \& Graf Publishers, 2006.

Dufresne, Ronald L., and Evan H. Offstein. "On the Virtues of Secrecy in Organizations," Journal of Management Inquiry 17, no. 2 (2008): 102-6.

Duncan, Ann Williams. "Religion and Secrecy: A Bibliographic Essay." Journal of the American Academy of Religion 74, no. 2 (2006): 469-82.

Emerson, Thomas. "The Danger of State Secrecy." The Nation, March 30, 1974.

Erickson, Patricia E., and James Flynn. "Secrecy as an Organizational Control

Strategy: Police Planning for a National Political Convention." In Secrecy: A

Cross-Cultural Perspective, edited by Stanton K. Tefft, 251-72. New York: Human Sciences Press, 1980.

Fallon, James. The Psychopath Inside: A Neuroscientist's Personal Journey Into the Dark Side of the Brain. New York: Current, 2013.

Farnsworth, Clyde H. "Canadian Agency Is Accused of Spying on Citizens and Allies." The New York Times, December 28, 1995. 
https://www.nytimes.com/1995/12/28/world/canadian-agency-is-accusedof-spying-on-citizens-and-allies.html

Feinberg, Joel. Freedom and Fulfillment: Philosophical Essays. Princeton:

Princeton University Press, 1992.

Fisher, Louis. "Congressional-Executive Struggles Over Information: Secrecy

Pledges," Administrative Law Review 42 (1990): 89-107.

Forcese, Craig. "The Judicialization of Extraterritorial Spying: Gaps and Gap-Fillers in the World of CSIS Foreign Operations." Criminal Law Quarterly 61 (2014): 440-50.

Foucault, Michel. History of Madness. London: Routledge, 2006. . L'archéologie Du Savoir. Paris: Gallimard, 1969.

Frost, Mike. Spyworld: Inside the Canadian and American Intelligence Establishments. Toronto: Doubleday Canada, 1994.

Gellhorn, Walter. Security, Loyalty, and Science. Ithaca: Cornell University Press, 1950.

Goffman, Erving. Behavior in Public Places. New York: The Free Press, 1963.

. Strategic Interaction. Philadelphia: University of Pennsylvania Press, 1971.

. The Presentation of Self in Everyday Life. Edinburgh: University of Edinburgh Press, 1956.

Goldman, Jan, and Susan Maret. Intelligence and Information Policy for National Security: Key Terms and Concepts. Lanham: Rowman \& Littlefield, 2016.

González, Roberto J. "Anthropology and the Covert: Methodological Notes on Researching Military and Intelligence Programmes." Anthropology Today 28, no. 2 (2012): 21-5.

Griffin, Ricky W., and Yvette P. Lopez. "When Employees Turn Violent." In Deviant and Criminal Behavior in the Workplace, edited by Steven M. Elias, 197220. New York: New York University Press, 2013.

Gunn, Joshua. Modern Occult Rhetoric: Mass Media and the Drama of Secrecy in the Twentieth Century. Tuscaloosa: The University of Alabama Press, 2005.

Gutmann, Amy, and Dennis Thompson. Democracy and Disagreement.

Cambridge: The Belknap Press of Harvard University Press, 1996.

Hamilton, Linda R. "Speaking Prose All Along: Scheppele's Legal Secrets." Law \& Social Inquiry 15, no. 3 (1990): 555-73. 
Hannant, Larry. The Infernal Machine: Investigating the Loyalty of Canada's Citizens. Toronto: University of Toronto Press, 1995.

Hayward, Keith. "Situational Crime Prevention and its Discontents: Rational Choice Theory versus the 'Culture of Now'," Social Policy \& Administration 41 , no. 3 (2007): 232-50.

Highmore, Ben. Ordinary Lives: Studies in the Everyday. London: Routledge, 2011.

Hildesheimer, Françoise. "Le Secret de l'État «moderne»." In Le Secret de l'État: Surveiller, Protéger, Informer XVIIe-XXe Siècle, edited by Sébastien-Yves Laurent, 11-50. Paris: Nouveau Monde éditions, 2015.

Hitz, Frederick. Why Spy? Espionage in an Age of Uncertainty. New York: Thomas Dunne Books, 2008.

Hobbes, Thomas. Leviathan. Edited by Richard Tuck. Cambridge: Cambridge University Press, 1988.

Hogg, Peter W., Patrick J. Monahan, and Wade K. Wright. Liability of the Crown. 4th ed. Toronto: Carswell, 2011.

Horn, Eva. "Logics of Political Secrecy." Theory, Culture \& Society 28, no. 7-8 (2011): 103-22.

Hume, L. J. Bentham and Bureaucracy. Cambridge: Cambridge University Press, 1981.

Hunt, Alan. "Marxism, Law, Legal Theory and Jurisprudence." In Dangerous Supplements: Resistance and Renewal in Jurisprudence, edited by Peter Fitzpatrick, 101-32. Durham: Duke University Press, 1991.

Johnson, Loch K., and James J. Wirtz, eds. Intelligence: The Secret World of Spies. An Anthology. 4th ed. Oxford: Oxford University Press, 2005.

Kaiser, Fred M. "Secrecy, Intelligence, and Community: The US Intelligence Community." In Secrecy: A Cross-Cultural Perspective, edited by Stanton K. Tefft, 273-96. New York: Human Sciences Press, 1980.

Kealey, Gregory S. "The Early Years of State Surveillance of Labour and the Left in Canada: The Institutional Framework of the Royal Canadian Mounted Police Security and Intelligence Apparatus, 1918-26." Intelligence and National Security 8, no. 3 (1993): 129-48.

. "The Surveillance State: The Origins of Domestic Intelligence and Counter Subversion in Canada, 1914-21." Intelligence and National Security 7, no. 3 (1992): 179-210. 
Kinsman, Gary, Dieter K. Buse, and Mercedes Steedman, eds. Whose National Security? Canadian State Surveillance and the Creation of Enemies. Toronto: Between the Lines, 2000.

Kinsman, Gary, and Patrizia Gentile. The Canadian War on Queers: National Security as Sexual Regulation. Vancouver: University of British Columbia Press, 2010.

Kumar, Miiko, Greg Martin, and Rebecca Scott Bray. "Secrecy, Law and Society." In Secrecy, Law and Society, edited by Greg Martin, Rebecca Scott Bray, and Miiko Kumar, 1-19. New York: Routledge, 2015.

Lane, Julie D., and Daniel M. Wegner. "The Cognitive Consequences of Secrecy." Journal of Personality and Social Psychology 69, no. 2 (1995): 237-53.

Laurent, Sébastien-Yves. "Travailler Sur «l'État Secret» Contemporain." Revue Internationale de Criminologie et de Police Technique et Scientifique, no. 3 (2016): 261-76.

Lefebvre, Stephane. "What Do Judges Say on the Protection of Intelligence Secrets?" Intelligence and National Security 34 (2019): 62-77.

. "Why Are State Secrets Protected from Disclosure? The Discourse of Secret Keepers," The International Journal of Intelligence, Security, and Public Affairs 20 (2018): 204-29.

Lester, Genevieve. When Should State Secrets Stay Secret? Accountability, Democratic Governance, and Intelligence. Cambridge: Cambridge University Press, 2015.

Lint, Willem de. "Intelligent Governmentality." Windsor Yearbook on Access to Justice 26 (2008): 279-312.

Lint, Willem de, and Sirpa Virta. "Security in Ambiguity: Towards a Radical Security Politics." Theoretical Criminology 8, no. 4 (2004): 465-89.

Lowry, Ritchie P. "Toward a Sociology of Secrecy and Security Systems." In Secrecy: A Cross-Cultural Perspective, edited by Stanton K. Tefft, 297-316. New York: Human Sciences Press, 1980.

Luhrmann, T. M. "The Magic of Secrecy." Ethos 17, no. 2 (1989): 131-65.

Maret, Susan. "The Charm of Secrecy: Secrecy and Society as Secrecy Studies." Secrecy and Society 1, no. 1, (2016). https://scholarworks.sjsu.edu/secrecyandsociety/vol1/iss1/1

Maret, Susan. "Introduction: Government Secrecy." In Government Secrecy, Research in Social Problems and Public Policy, vol. 19, edited by Susan 
Maret, xi-xxx. Howard House, UK: Emerald Publishing, 2011.

Maret, Susan, and Jan Goldman, eds. Government Secrecy: Classic and

Contemporary Readings. Westport: Libraries Unlimited, 2009.

Marx, Karl. "Critique of Hegel's Philosophy of Right." In Writings of the Young Marx on Philosophy and Society, edited by Lloyd D. Easton and Kurt H. Guddat, 152-202. New York: Doubleday, 1967. . Early Writings. London: Penguin Books, 1992.

Masco, Joseph. The Theater of Operations: National Security Affect from the Cold War to the War on Terror. Durham: Duke University Press, 2014.

McCraw, David, and Stephen Gikow. "The End to an Unspoken Bargain? National Security and Leaks in a Post-Pentagon Papers World." Harvard Civil RightsCivil Liberties Law Review 48 (2013): 473-509.

McCulloch, Jude, and Sharon Pickering. "Counter-Terrorism: The Law and Policing of Pre-Emption." In Counter-Terrorism and Beyond: The Culture of Law and Justice after 9/11, edited by Nicola McGarrity, Andrew Lynch, and George Williamns, 13-29. London: Routledge, 2010.

Mewett, Allan W. "State Secrets in Canada." Canadian Bar Review 63, no. 2 (1985): 358-77.

Mill, John Stuart. "On Liberty." In Collected Works of John Stuart Mill, vol. 18, edited by J. M. Robson, 213-310. Toronto: University of Toronto Press, 1977.

Miller, Seumas. Social Action: A Teleological Account. Cambridge: Cambridge University Press, 2001.

Miller, William Ian. Faking It. Cambridge: Cambridge University Press, 2003.

Moss, Lawrence. "Secrecy." In The Blackwell Encyclopedia of Sociology, edited by George Ritzer, 4140-43. Malden: Blackwell, 2007.

Moynihan, Daniel Patrick. Secrecy: The American Experience. New Haven: Yale University Press, 1998.

National Security Counselors et. al. v. Central Intelligence Agency et. al., Case 1:12-cv-00284-BAH (DC Col), Memorandum Opinion (November 16, 2016).

Neocleous, Mark. "Privacy, Secrecy, Idiocy." Social Research 69, no. 1 (2002): 85-110.

Neuberger, Lord. "Is Nothing Secret? Confidentiality, Privacy, Freedom of Information and Whistleblowing in the Internet Age." Singapore Academy of 
Law Annual Lecture, September 21, 2015, https://www.supremecourt.uk/docs/speech-150921.pdf

Offe, Claus. "The Theory of the Capitalist State and the Problem of Policy Formation." In Stress and Contradiction in Modern Capitalism, edited by Leon Lindberg, 125-44. Lexington: DC. Heath, 1975.

Oleson, Peter, ed. AFIO's Guide to the Study of Intelligence. Falls Church: Association of Former Intelligence Officers, 2016.

Ombrain, Nicholas d'. "Cabinet Secrecy." Canadian Public Administration 47, no. 3 (2004): 332-59.

Pels, Dick. Property and Power in Social Theory: A Study in Intellectual Rivalry. London: Routledge, 1988.

Peritz, Aki. "The CIA Doesn't Need a 'Glorious Loyalty Oath Crusade' to Keep Secrets." The Atlantic, (July 2, 2013). https://www.theatlantic.com/politics/archive/2013/07/the-cia-doesnt-needa-glorious-loyalty-oath-crusade-to-keep-secrets/277462/

Peters, B. Guy. The Politics of Bureaucracy. 5th ed. London: Routledge, 2001.

Pozen, David. "Deep Secrecy." Stanford Law Review 62, no. 2 (2010): 257-339.

Pringle, Robert W. Historical Dictionary of Russian and Soviet Intelligence. Lanham: Scarecrow Press, 2006.

Reed, Michael. "Beyond the Iron Cage? Bureaucracy and Democracy in the Knowledge Economy and Society." In The Values of Bureaucracy, edited by Paul du Guay, 115-40. Oxford: Oxford University Press, 2005.

Resnik, Judith. "Bring Back Bentham: 'Open Courts,' 'Terror Trials,' and Public Sphere(s)." Law \& Ethics of Human Rights 5, no. 1 (2011): 2-69.

Rigakos, George S., and Richard W. Hadden. "Crime, Capitalism and the 'Risk Society': Towards the Same Olde Modernity?" Theoretical Criminology 5, no. 1 (2001): 61-84.

Roberts, J. M. The Mythology of the Secret Societies. London: Watkins Publishing, 2008.

Robertson, Geoffrey, and Andrew Nicol. Media Law. 4th ed. London: Sweet \& Maxwell, 2002.

Robinson, Neil. "Bureaucracy." In Encyclopedia of Democratic Thought, edited by Paul Barry Clarke and Joe Foweraker. London: Routledge, 2001. 
Rosenberg, Daniel. "Data before the Fact." In "Raw Data" Is an Oxymoron, edited by Lisa Getelman, 15-40. Cambridge: The MIT Press, 2013.

Rosenblum, Nancy L. Bentham's Theory of the Modern State. Cambridge: Harvard University Press, 1979.

Sagar, Rahul. Secrets and Leaks: The Dilemma of State Secrecy. Princeton: Princeton University Press, 2013.

Sánchez Estop, Juan Domingo. "Wikileaks: From Abbé Barruel to Jeremy Bentham and Beyond (A Short Introduction to the New Theories of Conspiracy and Transparency)." Cultural Studies $\leftrightarrow$ Critical Methodologies 14, no. 1 (2014): 40-9.

Scheppele, Kim Lane. Legal Secrets: Equality and Efficiency in the Common Law. Chicago: The University of Chicago Press, 1988.

Schmitt, Carl. Die Diktatur: Von Den Anfängen Des Modernen Souveränitätsgedankens Bis Zum Proletarischen Klassenkampf. Berlin: Duncker and Humblot, 1995.

. The Nomos of the Earth in the International Law of the Jus Publicum Europaeum. New York: Telos Press, 2006.

Schofield, Philip. Utility and Democracy: The Political Thought of Jeremy Bentham. Oxford: Oxford University Press, 2006.

Schroen, Gary C. First In: An Insider's Account of How the CIA Spearheaded the War on Terror in Afghanistan. New York: Ballantine Books, 2005.

Schwarz, Jr., Frederick A. O. Democracy in the Dark / The Seduction of Government Secrecy. New York: The New Press, 2015.

Secrecy and Society. About.

https://scholarworks.sjsu.edu/secrecyandsociety/about.html

Shapiro, Jacob N., and David A. Siegel. "Is This Paper Dangerous? Balancing Secrecy and Openness in Counterterrorism." Security Studies 19, no. 1 (2010): 66-98.

Simmel, Georg. Sociology: Inquiries into the Construction of Social Forms, Volume 1. Edited by Anthony J. Blasi, Anton K. Jacobs, and Mathew Kanjirathinkal. Leiden: Brill, 2009.

. The Sociology of Georg Simmel. Edited by K. Wolff. New York: Free Press, 1950. 
. "The Sociology of Secrecy and of Secret Societies." The American Journal of Sociology XI, no. 4 (1906): 441-98.

Sissman, Adam. John Le Carré: The Biography. Toronto: Alfred A. Knopf Canada, 2015.

Stone, Corin R. Testimony before Congress. In Information Sharing in the Era of Wikileaks: Balancing Security and Collaboration, Hearing Before the Committee on Homeland Security and Governmental Affairs, United States Senate, 112th Congress, 1st Session, March 10, 2011, Senate Hearing 112-219. Washington, DC: US Government Printing Office, 2012, 9-10.

Taylor, Stan A. "Definitions and Theories of Counterintelligence." In Strategic Intelligence Vol. 4. Counterintelligence and Counterterrorism: Defending the Nation Against Hostile Forces, edited by Loch K. Johnson, 1-13. Westport: Praeger Security International, 2007.

Tefft, Stanton K. "Secrecy, Disclosure and Social Theory." In Secrecy: A CrossCultural Perspective, edited by Stanton K. Tefft, 35-74. New York: Human Sciences Press, 1980.

Thielmann, Greg. "From Intelligence Analyst to 'Citizen Watchdog.'" Foreign Service Journal (2004): 44-9.

Thompson, Dennis F. "Democratic Secrecy." Political Science Quarterly 114, no. 2 (1999): 181-93.

Turpin, Colin, and Adam Tomkins. British Government and the Constitution. 6th ed. Cambridge: Cambridge University Press, 2007.

United Kingdom, Intelligence and Security Committee of Parliament. "Privacy and Security: A Modern and Transparent Legal Framework," HC 1075, 2015. http://isc.independent.gov.uk/committee-reports/special-reports

United States v. Daoud, 755 F.3d 479 (7th Cir 2014).

Urban, Hugh B. "Secrecy and New Religious Movements: Concealment, Surveillance, and Privacy in a New Age of Information." Religion Compass 2, no. 1 (2008): 66-83.

_. "The Adornment of Silence: Secrecy and Symbolic Power in American Freemasonry." Journal of Religion and Society 3 (2001): 1-29.

. "The Torment of Secrecy: Ethical and Epistemological Problems in the Study of Esoteric Traditions." History of Religions 37, no. 3 (1998): 209-48.

Urmson, James O. Aristotle's Ethics. Oxford: Blackwell, 1988. 
Waldron, Jeremy J. "Hobbes and the Principle of Publicity." In Skepticism, Individuality, and Freedom: The Reluctant Liberalism of Richard Flathman, edited by Bonnie Honig and David R. Mapel, 189-211. Minneapolis: University of Minnesota Press, 2002.

Waller, Michael, and Andrew Linklater. "The Changing Face of Political Loyalty." In Political Loyalty and the Nation-State, edited by Michael Waller \& Andrew Linklater, 223-33. London: Routledge, 2003.

Weber, Max. "Bureaucracy." In From Max Weber: Essays in Sociology, edited by Hans H. Gerth and C. Wright Mills, 196-244. New York: Oxford University Press, 1946.

. "Bureaucracy." In Weber's Rationalism and Modern Society: New Translations on Politics, Bureaucracy, and Social Stratification, edited by Tony Waters and Dagmar Waters, 73-128. New York: Palgrave Macmillan, 2015.

. "Parliament and Government in Germany under a New Political Order." In Weber: Political Writings, edited by Peter Lassman and Ronald Speirs, 130271. Cambridge: Cambridge University Press, 1994.

Whitaker, Reg. "Cold War Alchemy: How America, Britain and Canada Transformed Espionage into Subversion." Intelligence and National Security 15, no. 2 (2000): 177-210.

. "Origins of the Canadian Government's Internal Security System, 19461952." The Canadian Historical Review LXV, no. 2 (1984): 154-83.

Whitaker, Reg, and Gary Marcuse. Cold War Canada: The Making of a National Insecurity State, 1945-1957. Toronto: University of Toronto Press, 1994.

Wiant, Jon A. "The Anthropology of Intelligence: Ethnographic Notes from the Field." A discussion paper presented at the 2007 International Studies Association Annual Convention.

Williams, Bernard. Essays and Reviews 1959-2002. Princeton: Princeton University Press, 2014.

Wilson, Valerie Plame. Fair Game: How a Top CIA Agent Was Betrayed by Her Own Government. New York: Simon \& Schuster Paperbacks, 2008.

Zedner, Lucia. "Pre-Crime and Post-Criminology?" Theoretical Criminology 11, no. 2 (2007): 261-81. 